\title{
Philosophical Reflection on the Value Hierarchy According to Max Scheler
}

\author{
Theodorus Christian Gunawan \\ Faculty of Philosophy, Widya Mandala Catholic University, Surabaya, Indonesia
}

\section{Email address:}

theodoruschristian09@gmail.com

\section{To cite this article:}

Theodorus Christian Gunawan. Philosophical Reflection on the Value Hierarchy According to Max Scheler. Advances in Sciences and Humanities. Vol. 7, No. 3, 2021, pp. 49-51. doi: 10.11648/j.ash.20210703.11

Received: May 19, 2021; Accepted: July 29, 2021; Published: August 18, 2021

\begin{abstract}
Axiology as a philosophical study has been in great demand since ancient Greece. There are quite a number of philosophers who have tried to discuss axiology. Problems and studies of axiology have developed along with the progress of the times. In the present era, axiology is increasingly being developed to study various contemporary issues related to values. One of the philosophers of axiology is Max Scheler. The German-born philosopher came up with the concept of value which is very a priori material in nature. This concept of value is included in understanding objective values. Scheler also created a hierarchy or level of values, starting from the lowest to the highest. The theory of Max Scheler regarding the hierarchy of values has had a significant influence on the development of the contemporary world; specifically regarding values and their application in everyday life. This hierarchy of values is certainly very influential for contemporary humans; especially to raise awareness and provide an understanding that needs to be related to which values need to be fought for and become a priority to be realized. Thus, Max Scheler's hierarchy of values has been very influential to date. This relevance is of course very important to be continuously reflected.
\end{abstract}

Keywords: Value, A Priorism, Material, Hierarchy, Objective, Max Scheler

\section{Introduction}

Axiology is one of the philosophical studies that is quite in demand at this time. This study has also existed since Ancient Greece. This can be seen in Plato's work entitled Phaedrus; where he discusses the value of beauty in humans [1]. Over time, philosophical studies of values are becoming increasingly popular in today's era.

One of the most famous philosophers of axiology is Max Scheler. Philosophical thinking and philosophical studies dwell on ethics and values. The influence of his thoughts on values and ethics is also felt even today. One of its contributions to world society is about the hierarchy of values; where it differentiates and ranks values.

In this paper, the author wants to discuss Max Scheler's thoughts about the hierarchy of values. The author will first begin by explaining the curriculum vitae of Max Scheler; to get to know the background of his thinking. Then the author will also briefly explain the value according to Max Scheler. Then, the author will explain the hierarchy of values according to Max Scheler. In the final section, the author will provide the relevance of Max Scheler's value hierarchy thinking for this era, as well as a reflection from the author himself. Thus, the author wants to show that Scheler's thinking is still very relevant at this time. Therefore, this paper is a philosophical reflection on the understanding or concept of the value hierarchy according to Max Scheler.

\section{Max Scheler's Life History and the Thoughts That Influenced Him}

Max Scheler was born in Munich, Southern Germany in 1874. In the area where he was born there are many people who are Catholic [2]. He is a German philosopher who has charming ideas and language style, and has emotional strength. This is certainly an inspiration for his theory. Scheler was very interested in the philosophical study of man and his problems, but death prevented him from dedicating a major work on philosophical anthropology. Scheler's own thinking was influenced by St. Augustine, Pascal, Nietzsche, and philosophers of vitalism [3]. 
In addition, he was also influenced by phenomenology, which emerged as a form of resistance to Kant's transcendentalist logicalism and empirical psychology. Thus, Scheler's understanding of axiology also has a connection or is connected to phenomenology [4]. Bergson's philosophy also influenced his thinking and personality, through which he believed that the whole human being, both spiritual and non-spiritual, is directed and driven to the act of loving the world; so that it is no longer to rule the world but for human existence itself.

He changed the meaning of phenomenology and he was also attracted to emotional intuition. From there, he tried to come up with emotional ideas and lowered the logic of the mind to the level of the heart. However, he did not succeed in building a system. However, his thinking about emotional intuition is a novelty, where previously there were quite a number of philosophers who eliminated the ability of human emotional intuition.

Scheler's life is divided into three periods. The first period is marked by activeness in undergoing studies; at this time he encountered the thoughts of Rudolf Eucken, the phenomenology of Husserl and the thoughts of Franz Brentano, which prompted him to produce a work entitled Der Formalismus in der Ethik which was published in 1922 [5].

The second period is marked by his activeness in producing works of thought, such as "Regarding Revolution in Values", "Immortality in Humans", and Der Formalismus in der Ethik und die materiale Wertethik, which contains the essence of Scheler's axiology [6].

The third period is marked by activity towards the end of his life, that is, when he moves from a theistic and Christian conception, to a completely different one from before, in which he studies the position of man in the cosmos. In this period he also rejected the conception of God, arguing that God is imperfect and is still in the process of becoming [7]. Philosophical anthropological thinking in the work The Position of Man in the Cosmos has greatly influenced contemporary thinking.

Later, his views on ethics were influenced by Kant's ethical formalism. He views Kant's ethics as supreme and perfect. However, he also harshly criticized him through his "Unqualified Judgment", and he called Kant's ethics a giant of steel and bronze [8]. However, he also saved Kant's ethics from accusations of formalism. Scheler's theory of material ethics reaffirms Kant's a priori principle, but according to Scheler there are two mistakes in Kant's ethics, namely that Kant confuses the a priori and the formal, and the confusion between the a priori and the rational [9].

Scheler added the side of material values and emotive apriorism. Kant's mistake occurred in equating formal and a priori, so that Kant rejected material ethics by accusing them of being too hedonistic and focusing on instinctive egoism [10]. Another mistake lies in Kant's rejection of material things, whereas according to Scheler the concept of ethics throughout the ages has always been based on existing objects. The existence of material objects is related to their purpose which is valuable or not. But, according to Scheler, goals are never free from values that must be realized. So, good or bad behavior is not measurable in its purpose.

Scheler also saw an advantage in Kant's ethics, namely that Kant tried to give up the ethics of goals and things. Thus, Scheler's ethical view is a combination of material and a priori, which then forms an axiological ethic. Thus, Scheler asserts that value does not depend on the objects and the content of the goal.

\section{Value According to Max Scheler}

Scheler argues that every human action is to realize values. The value referred to here is a quality that makes something valuable. Max Scheler argues that value is something that comes from the world of values. The existence of value itself does not depend on objects or objects that are empirical [11].

Max Scheler also emphasized that value has several characteristics which make it unique. The first attribute is material, thus value has certain contents such as delicious, strong, right, pure, and so on. The second quality is objective; this means that it has no dependence on human taste. The third attribute is a priori; that is not having dependence on the vehicle (eg "blue" even though it is not in itself, it is still understandable without the need to think about a blue motorbike or house. Thus, said Scheler, the value is as if "riding" or "being carried by" objects that are objects that can be called valuable.

Through such an understanding of value, Scheler can be classified as a philosopher of axiology who embraces axiological objectivism. Axiological objectivism itself is an understanding that believes that value is something that is truly objective. That way, the value is not affected at all by real objects or objects. Scheler also adds that value has an absolute nature; this absoluteness is attempted by Scheler to reject historical relativism. In addition, Scheler also understands value as something that is a priori emotional [12].

\section{Hierarchy of Value According to Max Scheler}

Max Scheler classifies values into four levels. The four levels Scheler distinguished from the lowest level to the highest level. The following will be explained by the author regarding the level or hierarchy of values by Max Scheler.

The first level or level is the values related to the good-bad values. This value is of course the lowest among the other values. The reason Scheler puts this value at the lowest is because these values are still closely related to mere pleasure or sensory satisfaction.

The second level or level of values is the values related to vital matters. Such values are of course important for the life of a human being; and therefore human beings need to realize these vital values. These vital values include: health, courage, and many more. Thus, these vital values are important in 
helping humans when they live their lives.

The third level is values related to or related to spiritual values. These spiritual values have three kinds, among others: first are aesthetic values such as beauty and ugliness; the second is the values of right-wrong and fair-unfairness; the third is the values of pure knowledge, which is like philosophy which means the beauty of knowledge in itself. These three kinds are always found in spiritual values.

Then, the fourth level or level which according to Scheler is the highest is religious values. These religious values are of course different from spiritual values, because they are still at a spiritual stage only. Meanwhile, religious values, such as the value of holiness and professional values are values that are at the highest level, and humans are expected to be able to direct their every action towards the values at this highest stage; namely religious value. The values contained at this level are also related to "absolute objects" and have transcendental properties that are applied and their development is in the religious field [13].

\section{Relevance and Reflection}

The value hierarchy according to Max Scheler provides contributions and contributions that are useful and tangible to human life. Scheler is able to provide differentiation according to the levels of values, from the lowest to the highest. These levels or degrees are of course very much needed and can provide a deep understanding of which values need to be manifested in one's life.

In the current era, where technological, information and scientific developments are increasingly developing, a basic understanding of which values should be fought for is of course a priority that must be put forward. The value hierarchy helps today's society to become aware of the values that need to be fought for in their lives. The fundamental problem related to this value hierarchy lies in realizing values. People in contemporary times today are often fooled into realizing the lowest values, that is, those based on the values of good and bad. This could be due to the spread of instant culture which causes people to strive for good values instantly, and avoid bad ones.

If people fall into choosing actions based only on momentary feelings, then people may only have an artificial quality of life and lack the depth of meaning of life; because of the result of living the values that are at the lowest level. Therefore, Max Scheler's Hierarchy of Value is about to help awaken and encourage people to go back to strive for actions that can realize values at the highest level; which according to Scheler are religious values.

From this, the author is able to reflect that the hierarchy of values according to Max Scheler really helps people today to have a deeper and more valuable quality of life. This is not to say that the scores at the lowest level are completely bad. The values at the lowest level also need to be pursued. Nevertheless, Scheler helps open people's eyes today to not only embody the lowest values. This means that human action today also needs to be open with efforts to realize higher values, even if they can be the highest; such as for example religious values.

\section{Conclusion}

Based on this discussion, the writer can conclude that value is something real and does not depend on the object or objects in question. The hierarchy of values that was triggered by Max Scheler can help people today in striving for a valuable life. This is based on Scheler's thinking which emphasizes that human action is an effort to realize values. Therefore, this hierarchy of values is very helpful for contemporary humans in showing which values need to be pursued. This does not mean that the lowest level of values does not need to be realized, but rather emphasizes that it is not the lowest values that are the first priority. According to Scheler's suggestion, the highest level of values is religious values; therefore, it needs to be pursued well, especially in the present era.

\section{References}

[1] Copleston, F. (1994) A History of Philosophy Volume IX: Modern Philosophy: From the French Revolution to Sartre, Camus, and Levi-Strauss, New York: Doubleday, 253.

[2] Parmono, R. (November 1993) "The Concept of Value According to Max Scheler", in the Philosophy Journal Series 16, Yogyakarta: Gadjah Mada University, 43.

[3] Frondizi, Risieri (2001) Introduction to the Philosophy of Values, Yogyakarta: Pustaka Pelajar, 102-103.

[4] Copleston, F. (1994) A History of Philosophy Volume IX: Modern Philosophy: From the French Revolution to Sartre, Camus, and Levi-Strauss, New York: Doubleday, 293.

[5] Frondizi, Risieri (2001) Introduction to the Philosophy of Values, Yogyakarta: Pustaka Pelajar, 104.

[6] Frondizi, Risieri (2001) Introduction to the Philosophy of Values, Yogyakarta: Pustaka Pelajar, 105.

[7] Frondizi, Risieri (2001) Introduction to the Philosophy of Values, Yogyakarta: Pustaka Pelajar, 106.

[8] Frondizi, Risieri (2001) Introduction to the Philosophy of Values, Yogyakarta: Pustaka Pelajar, 107.

[9] Frondizi, Risieri (2001) Introduction to the Philosophy of Values, Yogyakarta: Pustaka Pelajar, 107-108.

[10] Frondizi, Risieri (2001) Introduction to the Philosophy of Values, Yogyakarta: Pustaka Pelajar, 108.

[11] Frondizi, Risieri (2001) Introduction to the Philosophy of Values, Yogyakarta: Pustaka Pelajar, 114-115.

[12] Grunberg, Ludwig (2000) The Mystery of Values: Studies in Axiology, Atlanta: Rodopi, 09.

[13] Parmono, R. (November 1993) "The Concept of Value According to Max Scheler", in the Philosophy Journal Series 16, Yogyakarta: Gadjah Mada University, 49. 